\title{
Fungi in liverwort-based biocrust
}

\author{
Petra Landmark Gudmundsdottir and Olafur S. Andresson \\ Faculty of Life and Environmental Sciences, University of Iceland, Sturlugata 7, 101 Reykjavik, Iceland. \\ petralgu@gmail.com andosa@hi.is
}

\begin{abstract}
Fungal distribution in a liverwort-based biocrust was examined at different depths $(0,5$ and $20 \mathrm{~mm})$ by direct counting using both light and fluorescence microscopy. The DNA-based taxonomic composition of fungi was also determined and differences between depths (above and below $5 \mathrm{~mm}$ ) were assessed. The fungal biomass was greatest at the surface where large hyphae, sporangia and fungi within plants were more abundant than at 5 $\mathrm{mm}$ and $20 \mathrm{~mm}$ depth. The texture of the biocrust also differed significantly with depth. Likewise, the analysis of microbial DNA composition revealed a difference between depths, both for the amount of total fungi and of each phylum where the total amount of fungi was highest above $5 \mathrm{~mm}$. Ascomycota fungi were dominant both below $5 \mathrm{~mm}$ and near the surface where both their amount and proportion were substantially higher than deeper down. The dark septate Exophiala, Phialocephala and Pseudogymnoascus were the most abundant genera.
\end{abstract}

Keywords: biocrust, biological soil crust, fungal composition, fungal structure, microfungi, Iceland.

\section{YFIRLIT}

Sveppir i hélumosalifskurn

Sveppir í íslenskri hélumosalífskurn voru skoðaðir í ljóssmásjá og í flúrsmásjá. Munur á dreifingu sveppa var metinn eftir dýpi $(0,5,20 \mathrm{~mm})$ og flokkunarfræðileg samsetning hópa í lífskurninni var skoðuð ofan við $5 \mathrm{~mm}$ og neðan við $5 \mathrm{~mm}$. Munur var á áferð lífskurnar og útbreiðslu sveppa eftir dýpi. Lífmassi sveppa var meiri við yfirborð par sem breiðir svepppræðir, gróhirslur og sveppir á og í plöntum voru í meira magni en á $5 \mathrm{~mm}$ og 20 mm dýpi. Samsetningin var jafnframt mismunandi eftir dýpi hvað varðar heildarmagn sveppa og magn einstakra fylkinga. Heildarmagn sveppa var meira í sýnum ofan við $5 \mathrm{~mm}$ en neðar. Asksveppir voru ríkjandi í öllum sýnum, bæði ofan við $5 \mathrm{~mm}$ og neðan við $5 \mathrm{~mm}$ en peir voru í töluvert meira magni og hærra hlutfalli ofan við 5 mm en neðan. Dökkir sveppir af ættkvíslunum Exophiala, Pialocephala og Pseudogymnoascus voru algengastir.

\section{INTRODUCTION}

What is a biological soil crust?

Biological soil crusts or biocrusts are complex communities in the surface layer of the soil and often contain a mixture of various organisms such as bryophytes, lichens, green algae, fungi, cyanobacteria and other bacteria (Belnap et al. 2001, Belnap et al. 2016). Biocrusts are found in many open types of vegetation in various habitats worldwide such as deserts and other arid and dry environments, open woodlands, unforested grasslands, bare ground, and associated with alpine or tundra vegetation. Even though biocrusts are present in diverse environments they have similarities in function, as well as in composition and structure. For example, the structure of biocrusts in hot deserts throughout the world, in Australia and North and South America, is very similar, but distinctly different from biocrusts in cool and cold habitats 
such as those found on the Colorado Plateau and in the Great Basin of the United States and in the Arctic (Belnap 2001, Breen et al. 2008, Williams et al. 2017).

Climate strongly influences the type of biocrust present, especially in tundra environments (Williams et al. 2016, Rippkin et al. 2018). Availability of moisture affects biocrust abundance as well as composition (Borchhardt et al. 2017). The bryophyte component has higher moisture requirements than cyanobacteria and lichens. Well-developed biocrusts are generally not found in very dry areas. In dry areas biocrusts are usually in earlysuccessional stages and devoid of organisms with high moisture requirements such as bryophytes. In contrast, biocrusts in areas with high precipitation and low temperatures are often dominated by bryophytes (Bowker et al. 2016).

Vascular plants are very dependent upon water availability. Therefore, areas with limited water availability often have little vascular vegetation cover. Consequently, there is more soil surface available for biocrusts in these regions. Similarly, short growing seasons and low temperature can impede growth of vascular plants, favoring lichens, bryophytes and biocrusts. Biocrusts have a tendency to occupy bare soils and interspaces between vascular plants. In fact, it has been suggested that biocrusts don't compete with vascular plants and some studies have shown that vascular plants can benefit from growing on biocrusts (Belnap et al. 2001).

Biological soil crusts have different successional stages where early successional stages are often characterized by low species richness and domination of cyanobacteria which contribute both to carbon and nitrogen fixation. The cyanobacterial genus Microcoleus is often pronounced in early-successional biocrusts, whereas Nostoc and Scytonema spp. are more likely to be present in late successional stages (Belnap et al. 2001, Belnap et al. 2016).

In the top few millimeters of biological soil crust fungal hyphae and cyanobacterial filaments form a matrix that binds soil particles together.
This stabilizes and protects the soil surface (Belnap et al. 2001). The soil aggregation counteracts movement and displacement by water and wind, decreasing erosion and maintaining soil moisture. Therefore, biological soil crusts often act as seedbeds promoting establishment of vascular plants (Elmarsdottir et al. 2003, Zhang, Aradottir et al. 2016).

\section{Fungi in biocrust}

Biodiversity studies of biological soil crusts have so far focused on cyanobacteria and other bacteria as well as bryophytes and lichens that are components of well-developed biocrusts. There are very few studies on fungi in biocrust and they remain poorly characterized. These few studies are mostly descriptive and little is known about the correlation of fungal diversity with other factors such as nutrient cycling (Bates, Garcia-Pichel \& Nash 2010, Maier et al. 2016).

Well-developed biocrusts have greater fungal diversity and abundance than biocrusts in early successional stages. Furthermore, disturbance has a negative effect on fungal diversity in biocrusts (Bates et al. 2012, Bates, Nash et al. 2010, Maier et al. 2016). Bacterial abundance is higher than fungal abundance in biocrust. The bacterial-to-fungal ratio has been found to be between 1000:1 and 50:1, measured with rRNA copy numbers or with biomass estimations. The distribution and diversity of fungi has been found to be patchy, with some areas without hyphae while in others hyphae were abundant (Bates \& Garcia-Pichel 2009, Bates, Nash et al. 2010).

Microfungi are pronounced in biocrusts and can be free-living, mycorrhizal or saprophytic (Belnap et al. 2001). Although microfungi are believed to be more abundant in biocrust than in soil, this is based on very few studies. The phylum Ascomycota has been shown to be dominant in biocrust and genera such as Alternaria and Acremonium/Phoma are generally present in biocrusts (Bates \& Garcia-Pichel 2009, Bates, Nash et al. 2010, Bates et al. 2012, Bates, Nash et al. 2010, Maier et al. 2016).

Members of all the classical fungal phyla 
have been found in biological soil crusts. Most studies have found Ascomycota, Basidiomycota and Zygomycota (Bates, Garcia-Pichel \& Nash 2010, Bates et al. 2012, Bates, Nash et al. 2010, Zhang et al. 2018), but some have found only two of these phyla (Bates \& GarciaPichel 2009). Chytridiomycota have also been found in biocrust (Abed et al 2013, Steven et al. 2015). Ascomycota are the most dominant and have so far been found to account for over $80 \%$ of biocrust fungi (Abed et al. 2013, Bates \& Garcia-Pichel 2009, Bates, Garcia-Pichel \& Nash 2010, Bates et al. 2012, Bates, Nash et al. 2010, Zhang et al. 2018).

The order Pleosporales, within Ascomycota, is very prevalent in biocrusts and may represent the bulk of dark-septate fungi (dematiaceous fungi; with darkly pigmented hyphae or spores) (Abed et al. 2013, Bates \& Garcia-Pichel 2009, Bates, Garcia-Pichel \& Nash 2010, Bates, Nash et al. 2010, Bates et al. 2012, Steven et al. 2015). The cell walls of dark-septate fungi are rich in melanin which is thought to confer tolerance to many stress factors such as solar radiation and extreme temperatures, enabling these fungi to survive harsh conditions (Maier et al. 2016). Although the order Pleosporales is the most abundant and widespread, two other orders, Hypocreales within Ascomycota and Mortierellales within Zygomycota, have also been found to be widely distributed (Abed et al. 2013, Bates \& Garcia-Pichel 2009, Bates, Garcia-Pichel \& Nash 2010).

The most common genera in biocrust are the ascomycetes Alternaria/Lewia and Acremonium/Phoma (anamorph/teleomorph forms of the same species; asexual/sexual) (Abed et al. 2013, Bates \& Garcia-Pichel 2009, Bates, Garcia-Pichel \& Nash 2010, Bates, Nash et al. 2010, Maier et al. 2016, Grishkan \& Kidron 2013). Alternaria/Lewia appear to be the more abundant in biocrusts, although this is the other way around in soils. Fusarium, an ascomycete soil fungus, is also common in biocrust as well as the basidiomycete Cryptococcus (Bates, Garcia-Pichel \& Nash 2010, Bates et al. 2012). Not many yeasts have been found so far, although Exophiala crusticola has been identified in biocrust from the Colorado Plateau and other regions. E. crusticola is a black yeast, tolerant of extreme conditions such as shortage of nutrients and low water availability (Bates et al. 2006, Maier et al. 2016). Mortierella, mostly Mortierella alpina, is often found in biocrusts and is the most common zygomycete (Bates, Garcia-Pichel \& Nash 2010, Bates, Nash et al. 2010).

A Chinese study on fungi in biocrust found the composition to be different from previous studies in desert areas at the genus level and to vary greatly along successional gradients (Zhang et al., 2018). The genera Humicola, Endocarpon and Heteroplacidium were found to be dominant, whereas Alternaria/Lewia and Acremonium/Phoma were not detected. Humicola has previously been found in desert biocrusts (Bates, Garcia-Pichel \& Nash 2010).

Although publications show few major differences in biocrust fungal composition, most research so far has been done in deserts, mainly in the USA (Bates \& Garcia-Pichel 2009, Bates et al. 2012, Bates, Nash et al. 2010, Steven et al. 2016). There have been very limited studies on fungal composition in the arctic regions or other cool habitats (Broady \& Weinstein 1998, Zhang, Wang et al 2016). Therefore, the scenario described might be limited to these regions or habitats. In a Norwegian study on biocrust in a glacier foreland the most common fungi present in the biocrust were Lecythophora, Penicillum, Rhizoscyphus and Pholiota (Borchhardt et al. 2019). These fungi were not mentioned in the studies described above. Therefore, it would be interesting to find out which fungal genera dominate the Icelandic liverwort-based biocrust.

Fungi are believed to have an important ecological role in biocrusts. The fungal loop hypothesis (Perez-Moreno \& Read 2000) suggests that fungi play a key role in nutrient transport between patches of plants and adjacent areas in arid ecosystems where vegetation is scarce, in particular in linking nitrogen-limited plants with nitrogen-fixing biocrusts (Collins et al. 2008, Green et al. 2008). 


\section{Biocrust in Iceland}

In Iceland biological soil crusts can be found from the lowlands to the highlands. Biocrusts are present and among dominant features in 19 out of 64 terrestrial habitat types, within six habitat type classes: fell fields, moraines and sands, river plains, moss lands, lava fields, and wetlands and heathlands (Magnusson et al. 2016, Magnusson et al. 2009). The liverwort Anthelia juratzkana is often present and dominant in Icelandic biocrusts in the highlands. They are therefore referred to as liverwort biocrust or "hélumosaskán" or "mosaskorpa" in Icelandic (Hallgrimsson 2015).

The habitat types Boreal moss snowbed communities (EUNIS E4.115), Icelandic Racomitrium ericoides heaths (EUNIS E4.26) and Icelandic lava field lichen heaths (EUNIS E4.241) have the highest biocrust cover with the mean ranging between $25-35 \%$. Oroboreal moss-dwarf willow snowbed communities (EUNIS F2.112) have about 20\% biocrust cover, and Icelandic stiff sedge fens (EUNIS D4.1J) and Icelandic Salix lanata/S. phylicifolia scrub (EUNIS E2.113) have 10-15\% biocrust cover. Other habitat types have less than $10 \%$ biocrust cover. Biocrust is therefore substantial in over half of the highland vegetation cover (Magnusson et al. 2016).

The objectives of this study were:

1. To determine differences in biocrust fungal distribution and structure between depths $(0,5$ and $20 \mathrm{~mm})$ using light microscopy.

2. To quantify fungal hyphae, spores and sporangia in the biocrust by microscopic observation. Further, to estimate whether there is a difference in fungal biomass between depths $(0,5$ and $20 \mathrm{~mm})$ in the biocrust.

3. To determine the fungal composition by phylogenetic assignment of sequences from extracted DNA.

\section{MATERIALS AND METHODS \\ Study sites}

Samples of biocrust were collected from three study areas in South Iceland during the summer of 2016 (for maps and a table of study areas see Figures 2.1-2.3 and Table 2.1 in Gudmundsdottir 2018). Sample areas were selected based on profiles from the Icelandic Institute of Natural History. However, within the intentionally selected sampling areas, the sample points were selected randomly. The samples were stored at $-20^{\circ} \mathrm{C}$

The first study area was close to Thingvellir, at Gagnheidi [N 64 $22.053^{\circ} \mathrm{W} 21^{\circ} 03.768^{\prime}$ ] and Skjaldbreidur [N 64' $26.007^{\prime} \mathrm{W} 20^{\circ} 45.759^{\prime}$ ]. Two samples were taken at Gagnheidi on 24 May and two at Skjaldbreidur on 14 September. At Gagnheidi the areas chosen had been identified by the Icelandic Institute of Natural History as areas with Anthelia juratzkana. At Skjaldbreidur the vegetation was very sparse and no information was available on the vegetation at the time, although the vegetation has since been classified as Icelandic lava field shrub heaths (EUNIS E4.243) (Natturufraedistofnun Islands 2017).

The second study area was in Skaftartunga, within and close to the Vatnajokull National Park. Four samples were collected at Laki [N $64^{\circ} 03.511^{\prime} \mathrm{W} 18^{\circ} 14.532^{\prime}$ ] on 9 July within the national park and two at Fjallabaksleid sydri, close to Einhyrningur [N $63^{\circ} 49.078^{\text {' }}$ $\mathrm{W} 18^{\circ} 45.765^{\prime}$ ], and Svartihnukur [N $63^{\circ}$ $52.095^{\prime}$ W $18^{\circ} 44.137^{\prime}$ '] on 10 July. At Laki the samples were collected in Icelandic lava field lichen heaths (EUNIS E4.241) and Icelandic Racomitrium ericoides heaths (EUNIS E4.26). At Fjallabaksleid sydri they were collected in Boreal moss snowbed communities (EUNIS E4.115) (Magnusson et al., 2016).

The third study area was at Fridland ad fjallabaki, close to Hekla. Four samples were collected at Landmannaleid on 24 August. The Icelandic Institute of Natural History had not yet classified this area in heath types but the vegetation had been analyzed using aerial photographs. The samples collected at Landmannaleid were at sites with moss (EUNIS E4.26) [N 64 $\left.02.220^{\prime} \mathrm{W} 19^{\circ} 13.191^{\prime}\right]$ and sites with Anthelia juratzkana and willow (Salix) (EUNIS H5.2) [N 64 01.458' W $19^{\circ} 21.357^{\prime}$ '].

A total of fourteen samples were collected 
and for each sample six subsamples were taken, for a total of 84 subsamples. Two subsites were chosen, $\mathrm{A}$ and $\mathrm{B}$, for each sample and subsamples were taken at three depths, $0 \mathrm{~mm}$ (surface), $5 \mathrm{~mm}$ and $20 \mathrm{~mm}$.

\section{Structural observations}

The mount lactophenol cotton blue (LPCB) was prepared according to published procedures (Leck 1999, Parija \& Prabhakar 1995, Parija et al. 2003). $0.05 \mathrm{~g}$ methyl blue was added to $20 \mathrm{ml}$ of distilled water and left overnight to dissolve. The next day, $20 \mathrm{ml}$ of phenol solution were mixed with $20 \mathrm{ml}$ of lactic acid and then $40 \mathrm{ml}$ of $86-88 \%$ glycerol were added to the phenol lactic acid solution. The methyl blue solution was added to produce a lactophenol cotton blue (LPCB) mixture. Subsamples were stained with LPCB and fixed with 70\% alcohol. The slides were observed using 10x and 40x objectives in a Leica DM3000 light microscope and photographed with a Leica DFC290 camera using Leica Application Suite V3.1.0.

\section{Cross sections}

Cross sections were prepared using a razor blade by cutting a thin slice of the sample that was at least $5 \times 5 \mathrm{~mm}$. The slice was stained with calcofluor white and fixed with $10 \% \mathrm{KOH}$. The calcofluor white stain (18909 from SigmaAldrich) was a liquid solution ready for use (Rasconi et al. 2009). The slides were observed in a Leica DM6000 B fluorescence microscope at 50x magnification, using a 5x objective lens. Tile images were taken under UV light (filter cube A) for the fungal structures (calcofluor white observation) and under green light (filter cube TX2) for the autofluorescence of chloroplasts. Fiji was used to stitch the images and merge the tiled UV and green light images together (Preibisch et al. 2009, Rueden et al. 2017, Schindelin et al. 2012).

\section{Direct counting}

A mixture of $0.20 \mathrm{~g}$ subsample added to $20 \mathrm{ml}$ distilled water was stirred for an hour. $1 \mathrm{ml}$ of the subsample mixture was taken while stirring and collected on a $25 \mathrm{~mm}$ filter (Millipore
HAWP02500). Subsamples were stained with calcofluor white (Rasconi et al. 2009) and observed as above at 400x magnification. Ten positions were chosen randomly using the Mark\&Find panel and photographed. For each position, lengths and diameters of fungal structures were measured. For simplification, hyphal diameter was classified into three size groups: Small $(\leq 2.5 \mu \mathrm{m})$, medium (2.6-6.24 $\mu \mathrm{m})$ and large $(\geq 6.25 \mu \mathrm{m})$. The average values were chosen as small $1.75 \mu \mathrm{m}$, medium $4.42 \mu \mathrm{m}$ and large $6.5 \mu \mathrm{m}$.

\section{DAPI staining}

Sample were stained with DAPI (Sigma-Aldrich D9542) to visualize DNA and concomitantly with calcofluor white to stain fungi. Images were taken at 400x magnification under UV light (Filter cube A) for DNA and fungal structures, and under green light (Filter cube TX2) for the autofluorescence of cyanobacteria. The two fluorescent images were merged using Fiji (Rueden et al. 2017, Schindelin et al. 2012).

\section{Metagenome analysis}

Samples from Gagnheidi (study area 1) were used, from the same sites as sample 1 and sample 2 (see Table 2.1 in Gudmundsdottir 2018). Upper samples were above $5 \mathrm{~mm}$ depth and lower samples were below $5 \mathrm{~mm}$. Four upper samples were collected, two in May and two in September. Two lower samples were collected, both in September. Four random subsamples of $0.5 \mathrm{~g}$ each were dried, pooled and hand homogenized with a pestle in a clean baked mortar; $0.25 \mathrm{~g}$ of this material was extracted using the DNeasy PowerLyzer PowerSoil Kit (QiaGen). DNA sequencing libraries were generated with the Illumina Nextera XT kit and 2x 150 base sequences generated with a MiSeq v.2 sequencing kit. This produced approximately $300 \mathrm{Mb}$ of data for each sample which were subjected to metagenomic analysis on the Kaiju web site (Menzel et al. 2016) in the default "Greedy" mode. The resulting classification data was downloaded and summaries of the fungal data produced. 


\section{Statistical analysis}

Statistical analysis was done using R-3.4.3 and RStudio 1.1.423 (R-Core-Team 2017, RStudio 2018). For additional information on statistical methods see Gudmundsdottir (2018).

\section{RESULTS}

\section{Fungal distribution}

The distribution of fungi was classified as "patchy dumped", "random" or "none". Single hyphae and small mycelia had a random distribution, while larger mycelia and sporangia had a patchier distribution. In some cases where the distribution was classified as "none" fungi were only found on or inside plants. The biocrust texture differed between subsamples and was classified as "coarse", "mixed" or "muddy", with mixed being a mixture of coarse and muddy. Where the texture was coarse, fungi were often found as single hyphae or a few hyphae.

Cross sections were taken of all samples from all study sites. The cross-section samples all had a fungal layer at the surface (bluish fluorescence with calcofluor white). Liverworts were often abundant below ground as well as at the surface (red fluorescence; see Figure 1).

\section{Fungi at the surface}

Fungi in surface subsamples were often found as mycelia. Some had mostly small hyphae (Figure 2a, f) while others also showed larger

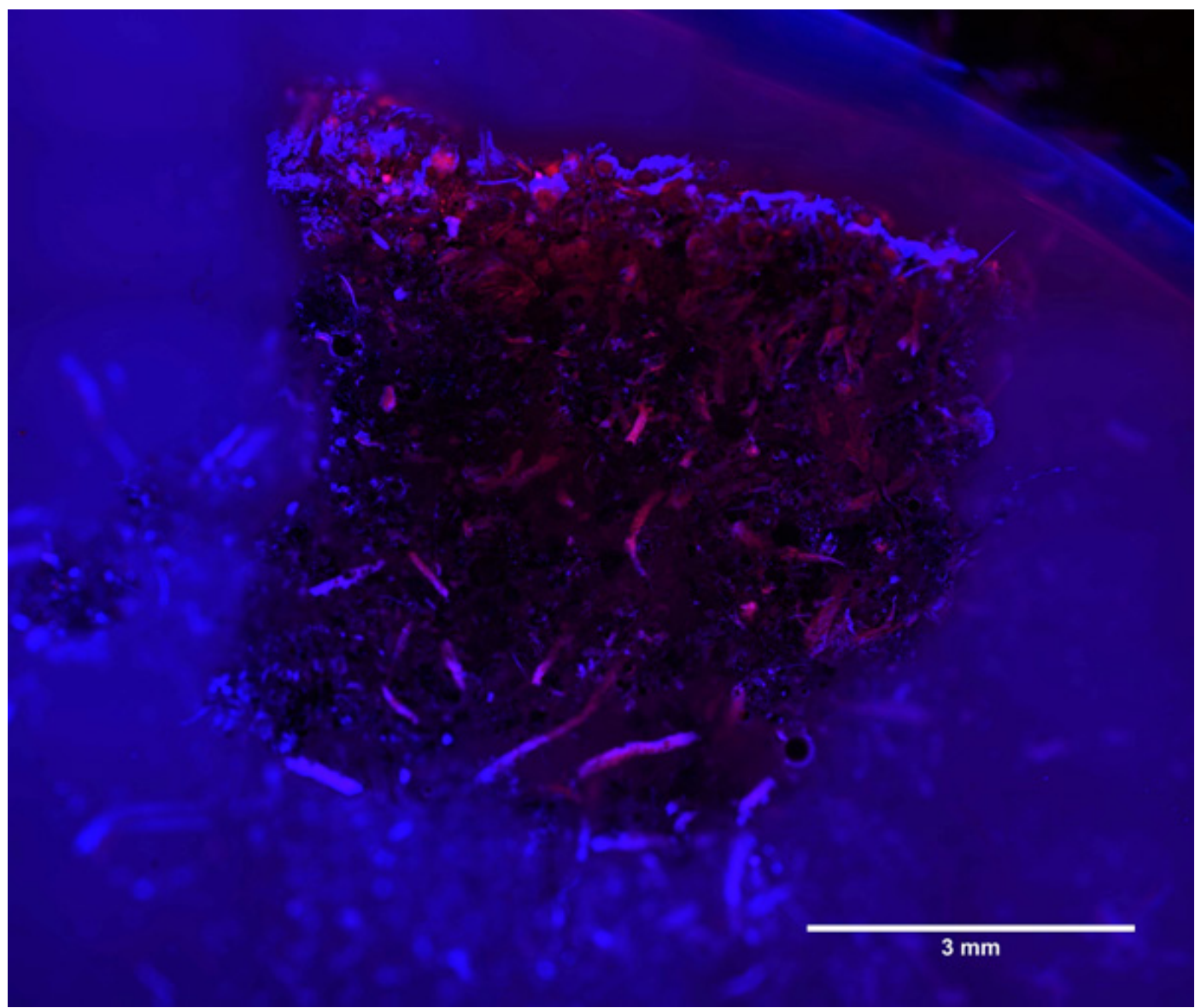

Figure 1. Cross section of sample 12 from Landmannaleið (study area 3) from a site with Anthelia and willow. The sample was stained with calcofluor white and examined under a fluorescence microscope with 50x magnification. Bluish fluorescence shows fungi and red shows chloroplasts (Anthelia). 
a)

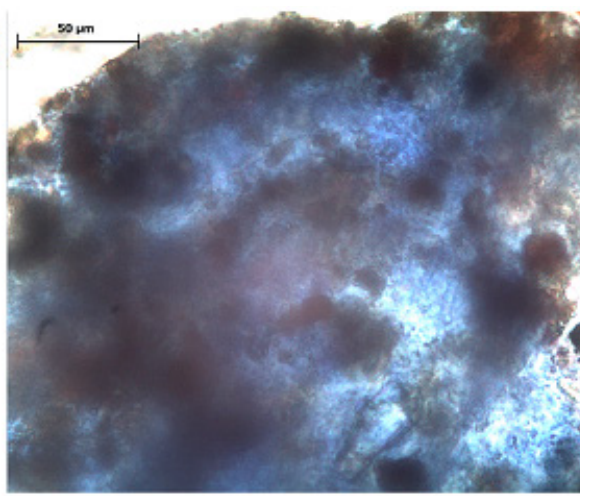

c)

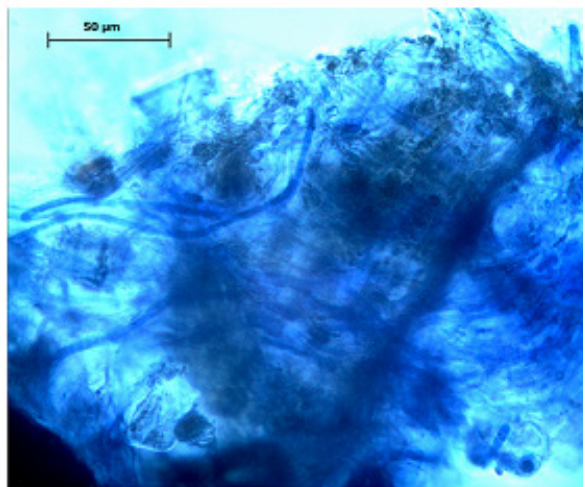

e)

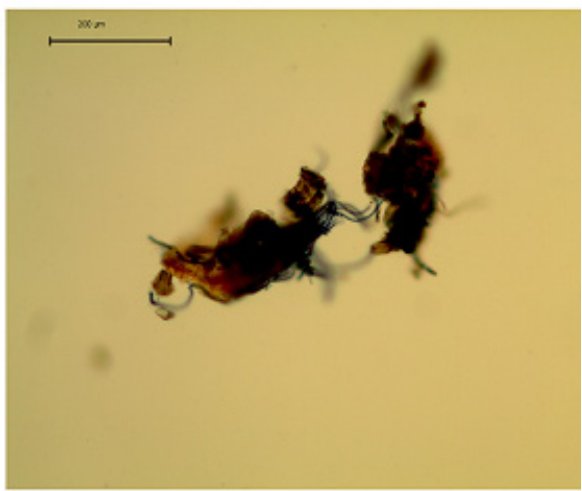

b)

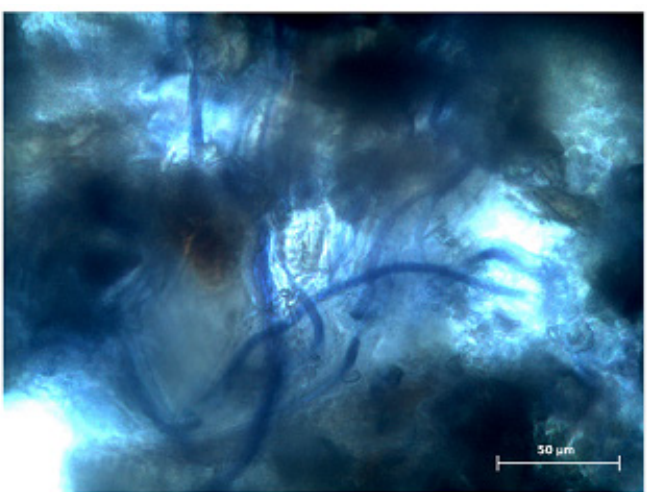

d)

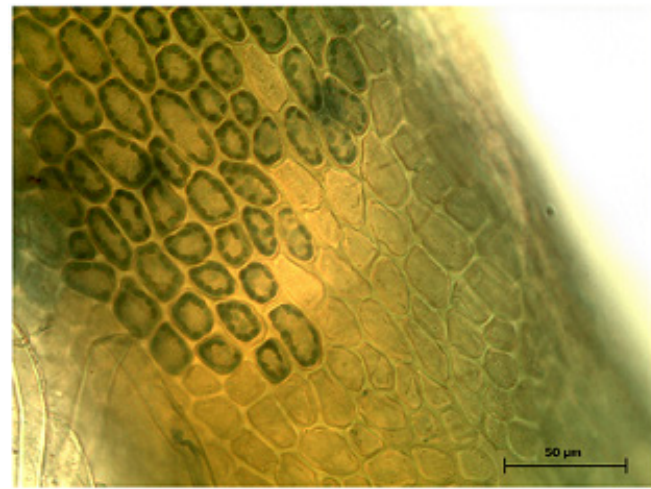

f)

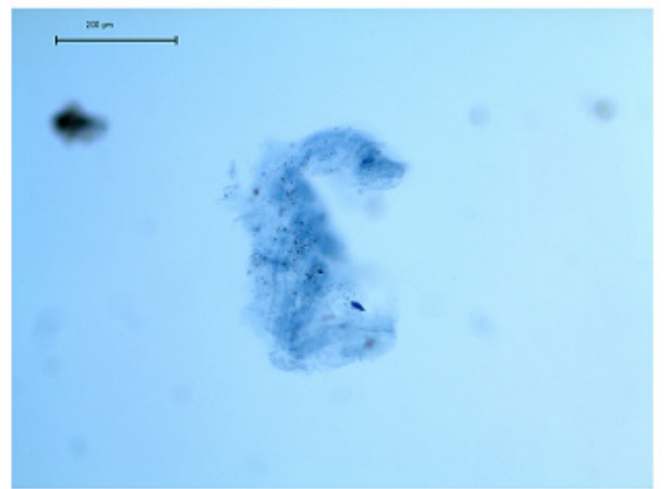

Figure 2. Mycelia in surface subsamples stained with lactophenol cotton blue and examined with 100x and 400x magnification. a-d) have a scale bar of $50 \mu \mathrm{m}$. e-f) have a $200 \mu \mathrm{m}$ scale bar. a) sample 2, b) sample 3, c) sample 17, d) sample 2, e) sample 4 and f) sample 12 .

hyphae (Figure 2b, c). Figure 2e shows hyphae binding soil particles together.

In this study sporangia were common in surface subsamples and formed the bulk of the fungal volume in one sample from area 1 which was taken in early summer (see Figure 3.24 in
Gudmundsdottir 2018). The sporangia in Figure $3 \mathrm{~b}$ show long, forked and greenish asci, often observed. Another commonly seen sporangium type contained 4 spores (sometimes 2 or 3 ) and had a round shape and red color (Figure $3 \mathrm{c}$ ). The sporangia in Figure 3a have a round shape, are 
a)

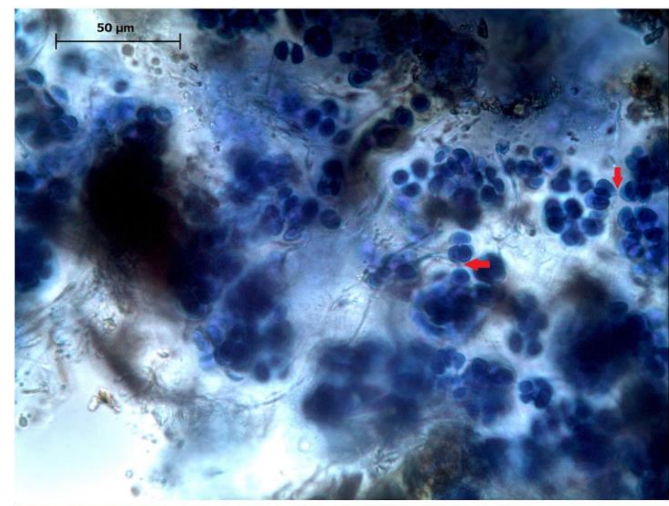

b)

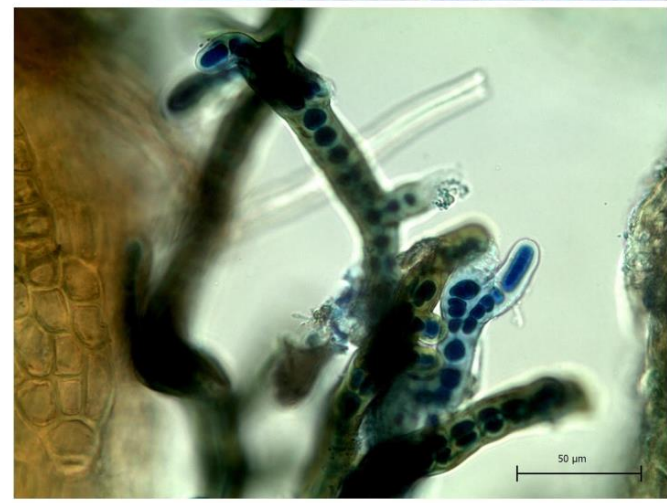

c)

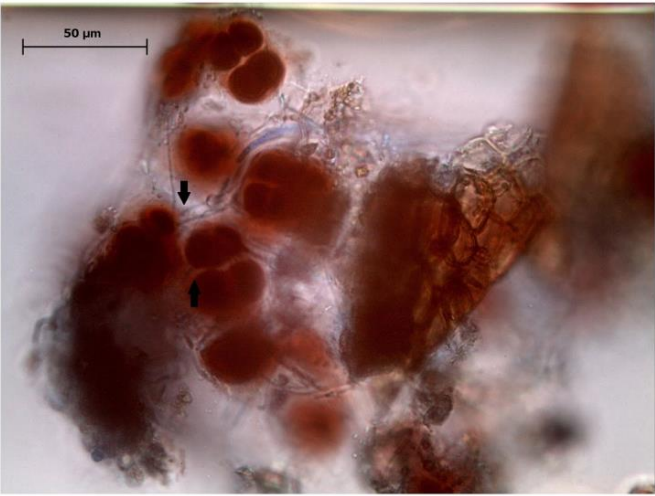

Figure 3. Sporangia in surface subsamples stained with lactophenol cotton blue and examined with $100 x$ and 400x magnification. The images have $50 \mu \mathrm{m}$ scale bars. a) round asci (sample 2), b) long, forked asci (sample 11) and c) round, red asci that often contain 4 spores (sample 16). In a and $\mathrm{c}$ arrows point to connections between fungal hyphae and sporangia. d)

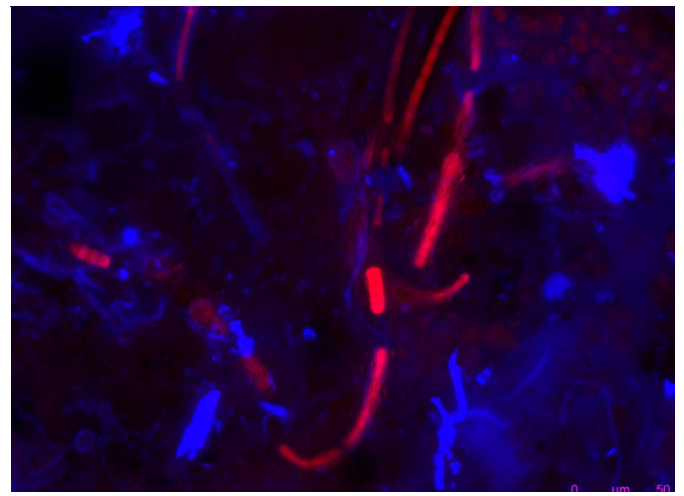

Figure 4. Fungi, cyanobacteria and bacteria in a surface subsample from sample 2 stained with DAPI and calcofluor white. $400 \mathrm{x}$ magnification in a fluorescence microscope. Both DAPI and calcofluor white fluorescence blue, whereas the red autofluorescence is from cyanobacteria.

transparent and contain many spores. In some cases, a connection can be seen between hyphae and sporangia (Figure 3a, c). Figure 3 shows the most common sporangia found and they are all asci of ascomycete fungi (see Figure 3.8 in Gudmundsdottir 2018).

Fungi were often abundant within plant tissues in surface subsamples and often appeared to be intracellular. Spores in surface subsamples were diverse in shape and size. They were often between 5-30 $\mu \mathrm{m}$. In Figure 4 cyanobacteria, fungi and bacteria can be seen in the biocrust surface layer.

\section{Fungi at $5 \mathrm{~mm}$ and $20 \mathrm{~mm}$}

At $5 \mathrm{~mm}$ and $20 \mathrm{~mm}$ depth mycelia were not as patchy as at the surface. Long hyphae were observed, often one or a few together (Figure 5). No significant differences in hyphal volumes were detected except for a single sample from study area 3 taken at $5 \mathrm{~mm}$ (see Figure 3.22 in Gudmundsdottir 2018). At $5 \mathrm{~mm}$ and 20 $\mathrm{mm}$ depth sporangia were not as abundant as in surface subsamples although they could be found, usually one or a few. The types of sporangia and spore shapes and sizes looked similar to those found at the surface. Fungi within plant tissues were most abundant at the 
a)

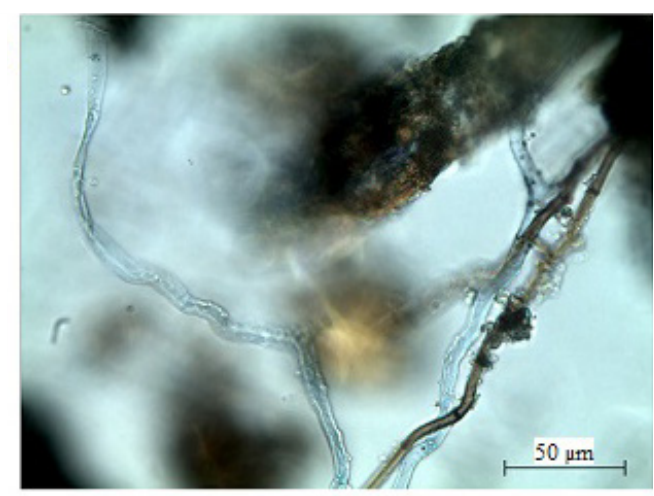

c)

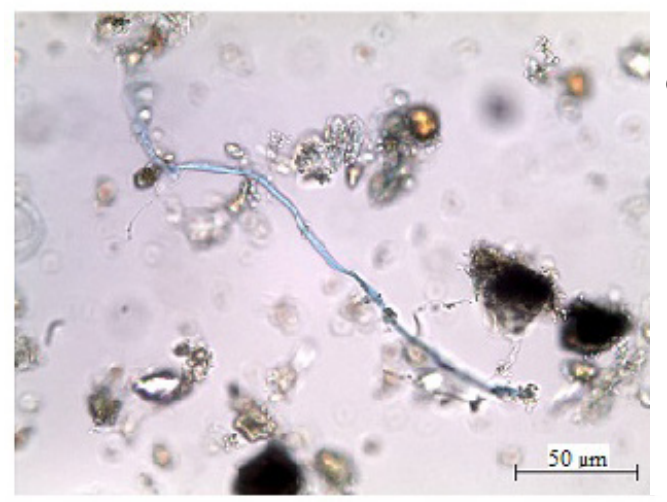

b)

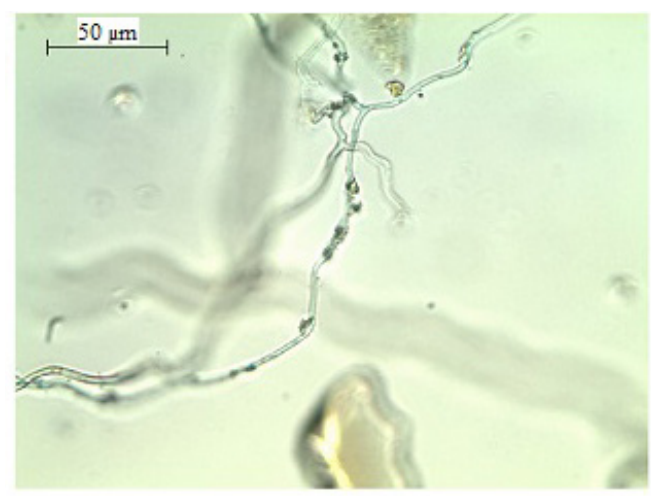

d)

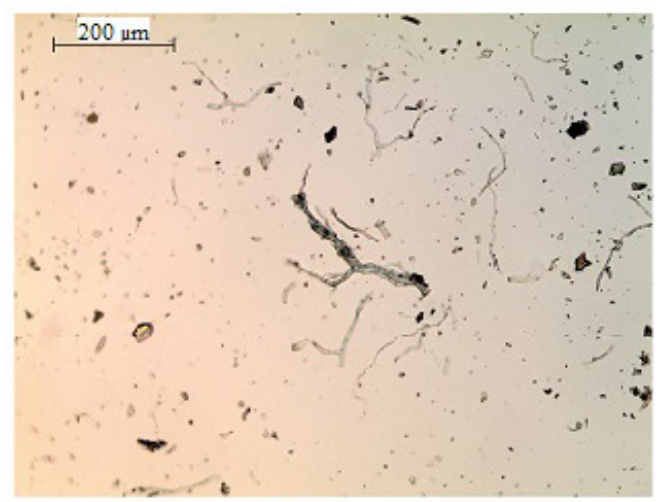

Figure 5. Hyphae at $5 \mathrm{~mm}$ and $20 \mathrm{~mm}$ depth stained with lactophenol cotton blue and examined under a light microscope at 100x and 400x magnification. a-c) have $50 \mu \mathrm{m}$ scale bars. d) has a $200 \mu \mathrm{m}$ scale bar. a) sample 2 at $5 \mathrm{~mm}$, b) sample 3 at $5 \mathrm{~mm}$, c) sample 1 at $20 \mathrm{~mm}$ and d) sample 5 at $20 \mathrm{~mm}$.

surface, and at $5 \mathrm{~mm}$ and $20 \mathrm{~mm}$ depth the plants looked battered and decaying.

\section{Estimation of variability in quantification}

Two kinds of estimates were made of variability in the quantification of fungal biomass. On one hand, four slides were prepared from the same subsample mixture and on the other hand, the images taken for one slide were assessed four times (repetitions). Consistency was assessed by one-way ANOVAs of the different slides ( $p$ $=0.9802)$ on one hand and the repetitions $(\mathrm{p}=$ 0.9999 ) on the other.

\section{Distribution of fungal features in biocrust}

In Table 1 biocrust texture and structural features of fungi are shown in relation to depth. Hyphae with a diameter $\leq 2.5 \mu \mathrm{m}$ were classified a small, hyphae 2.6-6.24 $\mu \mathrm{m}$ as medium, and hyphae $\geq 6.25 \mu \mathrm{m}$ as large. If distribution was marked as "no distribution", the fungi were only on or inside plants. Texture, distribution, on or inside plants, hyphal volume within plants, sporangial volume and volume of medium and large hyphae all showed significant differences between depths in the biocrust. The soil texture was more likely to be muddy at the surface (at 0 $\mathrm{mm}$ ) and coarse below ground (at 5 and $20 \mathrm{~mm}$ depth). The fungal distribution was patchy at the surface but more random below ground. The presence of fungi on or inside plant tissues was common at the surface but less so below ground. Hyphal volume within plants, sporangial volume and volume of large hyphae all decreased with depth. On the other hand, hyphal volume outside plants, spore volume and volume of small hyphae did not show a difference between depths. For additional information on statistical 
Table 1. Texture of biocrust and structural features of fungi in relation to depth. For categorical variables number of subsamples $(\mathrm{N})$ are shown for each category within variable and p-values are from chi-squared tests. For continuous variables mean and standard deviation (sd) are shown and p-values are from one-way ANOVAs. * stands for statistically significant. Volumes are in picoliters (pl).

\begin{tabular}{|c|c|c|c|c|c|}
\hline & \multicolumn{3}{|c|}{ Depth } & \multirow[t]{2}{*}{ P values } \\
\hline & & $0 \mathrm{~mm}$ & $5 \mathrm{~mm}$ & $20 \mathrm{~mm}$ & \\
\hline \multirow[t]{2}{*}{ Variables } & Group & $\mathrm{N}=28$ & $\mathrm{~N}=28$ & $\mathrm{~N}=28$ & \multirow{4}{*}{$<0.001^{*}$} \\
\hline & coarse & 14 & 16 & 22 & \\
\hline \multirow[t]{2}{*}{ Texture (n) } & mixed & 3 & 11 & 6 & \\
\hline & muddy & 11 & 1 & 0 & \\
\hline \multirow[t]{3}{*}{ On or inside plants (n) } & yes & 26 & 11 & 7 & \multirow[b]{2}{*}{$<0.001 *$} \\
\hline & no & 2 & 17 & 21 & \\
\hline & no & 10 & 6 & 3 & \multirow{3}{*}{$<0.001^{*}$} \\
\hline \multirow[t]{2}{*}{ Distribution (n) } & patchy dumped & 15 & 6 & 4 & \\
\hline & random & 3 & 16 & 21 & \\
\hline \multicolumn{2}{|c|}{ Hyphal volume (pl) (outside plants) (mean (sd)) } & $356(1,750)$ & $26.2(17.2)$ & $20.0(13.0)$ & 0.367 \\
\hline \multicolumn{2}{|c|}{ Hyphal volume (pl) (within plants) (mean (sd)) } & $2,410(3,520)$ & $318(569)$ & $468(1,280)$ & $0.001 *$ \\
\hline \multicolumn{2}{|c|}{ Spores volume (pl) (mean (sd)) } & $9.65(18.8)$ & $28.0(106)$ & $33.5(113)$ & 0.587 \\
\hline \multicolumn{2}{|c|}{ Sporangial volume (pl) (mean (sd)) } & $13.5(28.0)$ & $0.054(0.21)$ & $0.29(1.52)$ & $0.003 *$ \\
\hline \multicolumn{2}{|c|}{ Volume of small hyphae (pl) (mean (sd)) } & $337(1750)$ & $5.08(3.05)$ & $7.28(11.3)$ & 0.372 \\
\hline \multicolumn{2}{|c|}{ Volume of medium hyphae (pl) (mean (sd)) } & $6.59(6.74)$ & $13.4(13.0)$ & $8.97(7.50)$ & $0.027^{*}$ \\
\hline \multicolumn{2}{|c|}{ Volume of large hyphae (pl) (mean (sd)) } & $12.2(9.01)$ & $7.72(10.2)$ & $3.84(5.77)$ & $0.002 *$ \\
\hline
\end{tabular}

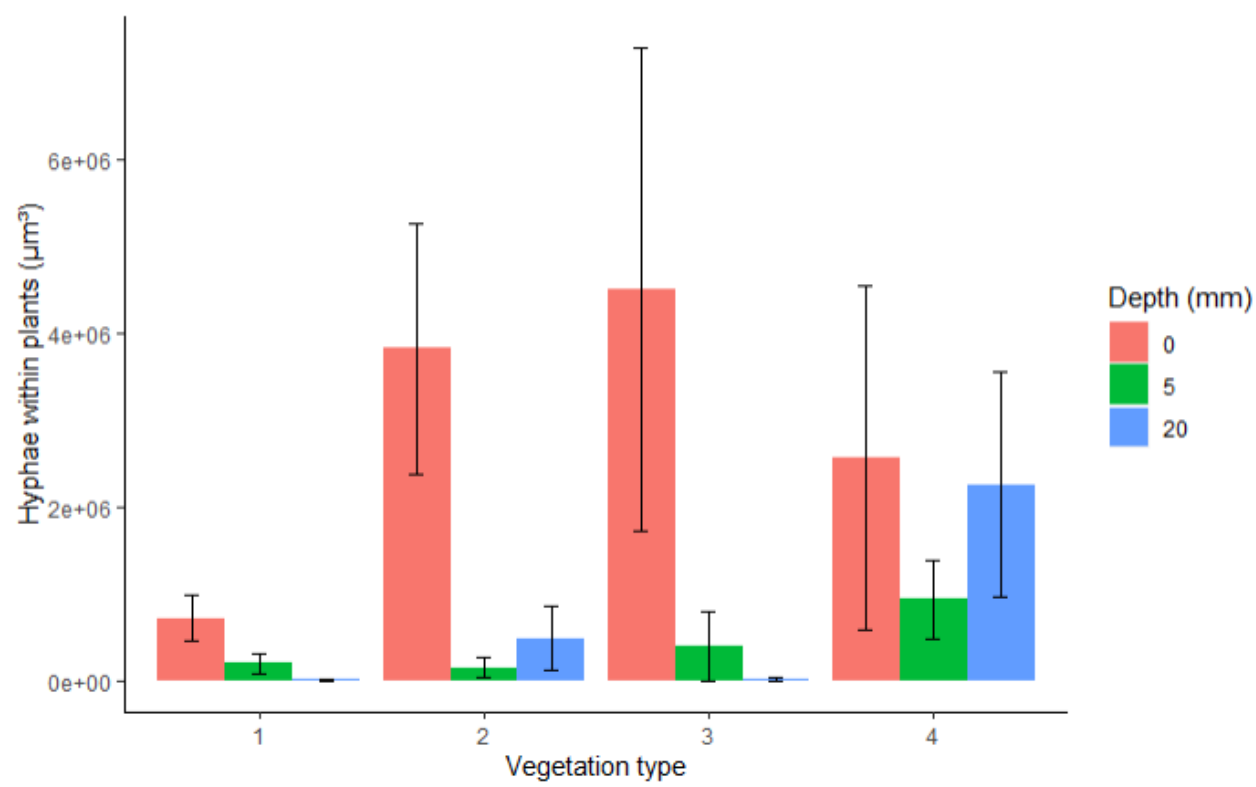

Figure 6. Hyphal volume within plants shown in relation to depth and vegetation type. Error bars are standard deviation of the mean. Vegetation types are 1) Boreal moss snowbed communities (EUNIS E4.115) and areas with Anthelia, 2) Icelandic Racomitrium ericoides heaths (EUNIS E4.26), 3) Icelandic lava field lichen heaths (EUNIS E4.241) and 4) Icelandic lava field shrub heaths (EUNIS E4.243). 
Table 2. Amount (in reads) within samples of total fungi and fungal phyla are shown in relation to depth in biocrust. Mean and standard deviation (sd) are shown for all variables and p-values are from one-way ANOVAs. Upper samples are above $5 \mathrm{~mm}$ in depth, lower samples are below $5 \mathrm{~mm}$ depth. * stands for statistically significant.

\begin{tabular}{llll}
\hline & \multicolumn{1}{c}{ Upper } & \multicolumn{1}{c}{ Lepth } & Pvalues \\
& \multicolumn{1}{c}{$\mathrm{N}=4$} & $\mathrm{~N}=2$ & \\
\hline Variables & $278,542(64,813)$ & $17,971(11,440)$ & $0.006^{*}$ \\
Total amount of fungi (mean (sd)) & $262,770(63,530)$ & $12,273(9,385)$ & $0.006^{*}$ \\
Ascomycota amount (mean (sd)) & $10,728(1,332)$ & $4,345(1,555)$ & $0.006^{*}$ \\
Basidiomycota amount (mean (sd)) & $1,880(206)$ & $808(267)$ & $0.005^{*}$ \\
Zygomycete fungi amount (mean (sd)) & $389(47)$ & $200(40)$ & $0.009^{*}$ \\
Chytridiomycota amount (mean (sd)) & $2,775(490)$ & $348(197)$ & $0.003^{*}$ \\
Other phyla amount (mean (sd)) & &
\end{tabular}

methods see Gudmundsdottir 2018.

Univariate analysis showed that depth and also the interaction between depth and vegetation type on hyphal volume within plants was significant where hyphae within plants were often in greater amounts at the surface than lower down, especially in Boreal moss snowbed communities and areas with Anthelia, Icelandic lava field lichen heaths and moss (Figure 6).

Univariate analysis also showed that sporangial volume was significantly correlated to depth. Sporangial volume was considerably higher in surface subsamples $(0 \mathrm{~mm})$ than the below ground subsamples $(5 \mathrm{~mm}$ and 20 $\mathrm{mm}$ ) (Table 1). There does not appear to be a significant difference between sporangial volumes at $5 \mathrm{~mm}$ and $20 \mathrm{~mm}$ depths. Univariate analysis showed a significant effect of depth on the volume of large hyphae where the volume of large hyphae increased greatly at the surface (0 $\mathrm{mm}$ ) (Table 1).

\section{Fungal composition}

The samples collected for metagenomic analysis were all from two sampling sites in study area 1 (Gagnheidi), the same as for sample 1 and sample 2. Upper level samples were collected both in May and September and they did not show a significant difference in total fungal amount or proportions of phyla. However, a significant difference was found between depths (Table 2). The total amount of fungi was consistently higher in upper samples than lower samples (Table 2).

Also, in the upper samples the mean proportion of ascomycetes was $94 \%$ of total fungi, while in the lower samples the mean proportion was $65 \%$. Although the proportion of basidiomycetes increased from $4 \%$ in the upper samples to $27 \%$ in the lower samples, they were still in lower absolute numbers due to the substantially smaller total number of fungi in the lower level.

Zygomycete fungi, which encompass the phyla Zoopagomycota and Mucoromycota (Spatafora et al.2016), were found in much lower numbers. A low level of sequence reads for the phyla Microsporidia, Neocallimastigomycota, Cryptomycota and Blastocladiomycota was found in all samples.

A total of 105 orders were found (Table 3). Thereof, Ascomycota had 52, Basidiomycota 37 , zygomycete fungi 10 , Chytridiomycota 3 and other fungi 2 orders. In the upper biocrust samples the top 32 fungal genera with over 2000 reads were all Ascomycota (Figure 7). The genera fell within 11 orders. The most abundant genera were Exophiala, Phialocephala and Pseudogymnoascus, with over 10,000 reads. Aspergillus, Endocarpon and Oidiodendron were also abundant.

In the lower biocrust samples the top fungal genera, with over 200 reads, were within Ascomycota and Basidiomycota. Zygomycete 
Table 3. All orders found within the liverwort-based biocrust samples. Orders marked in red are not present in fungi lists of microfungi in Iceland (Hallgrimsson 2010, Hallgrimsson \& Eyjolfsdottir 2004).

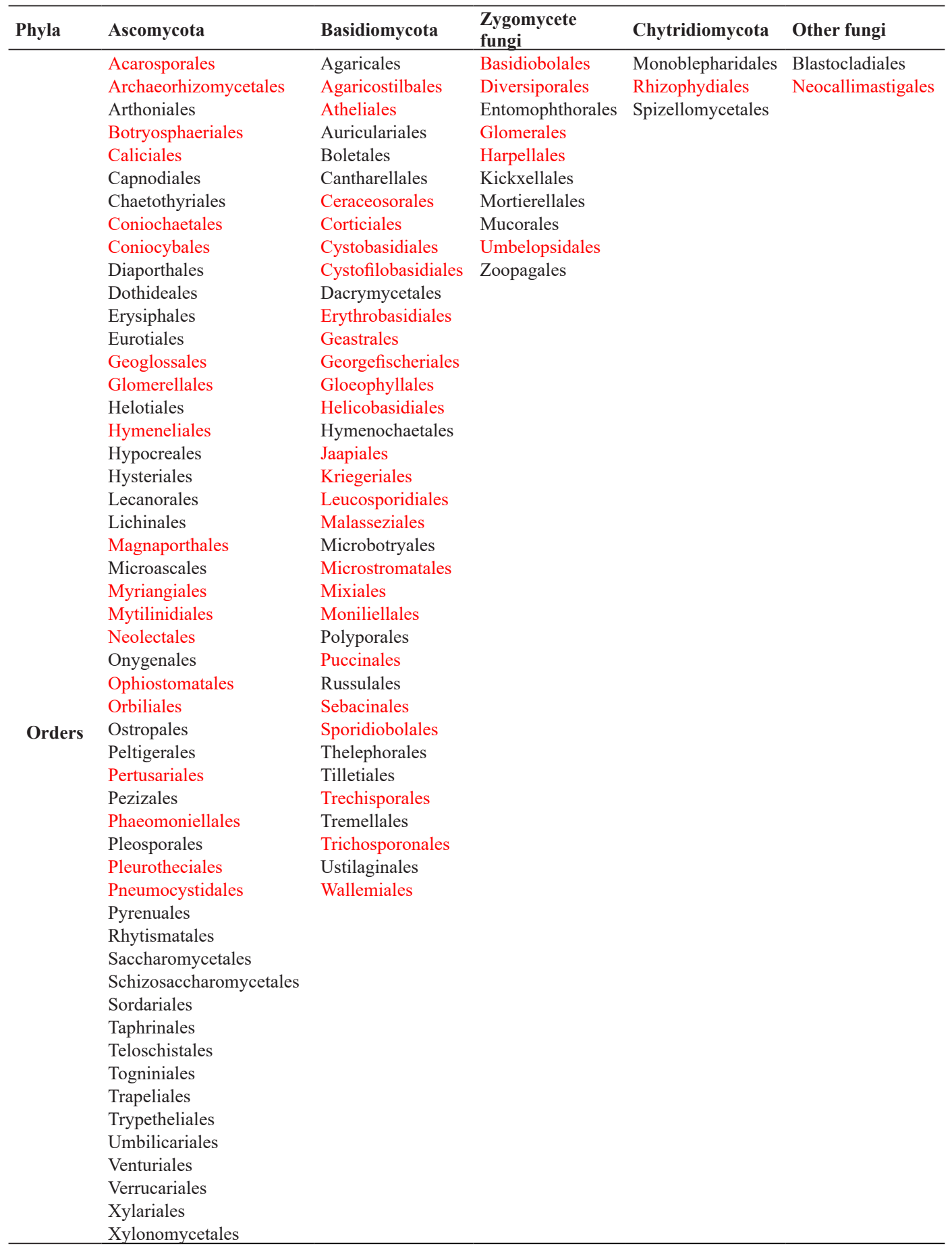




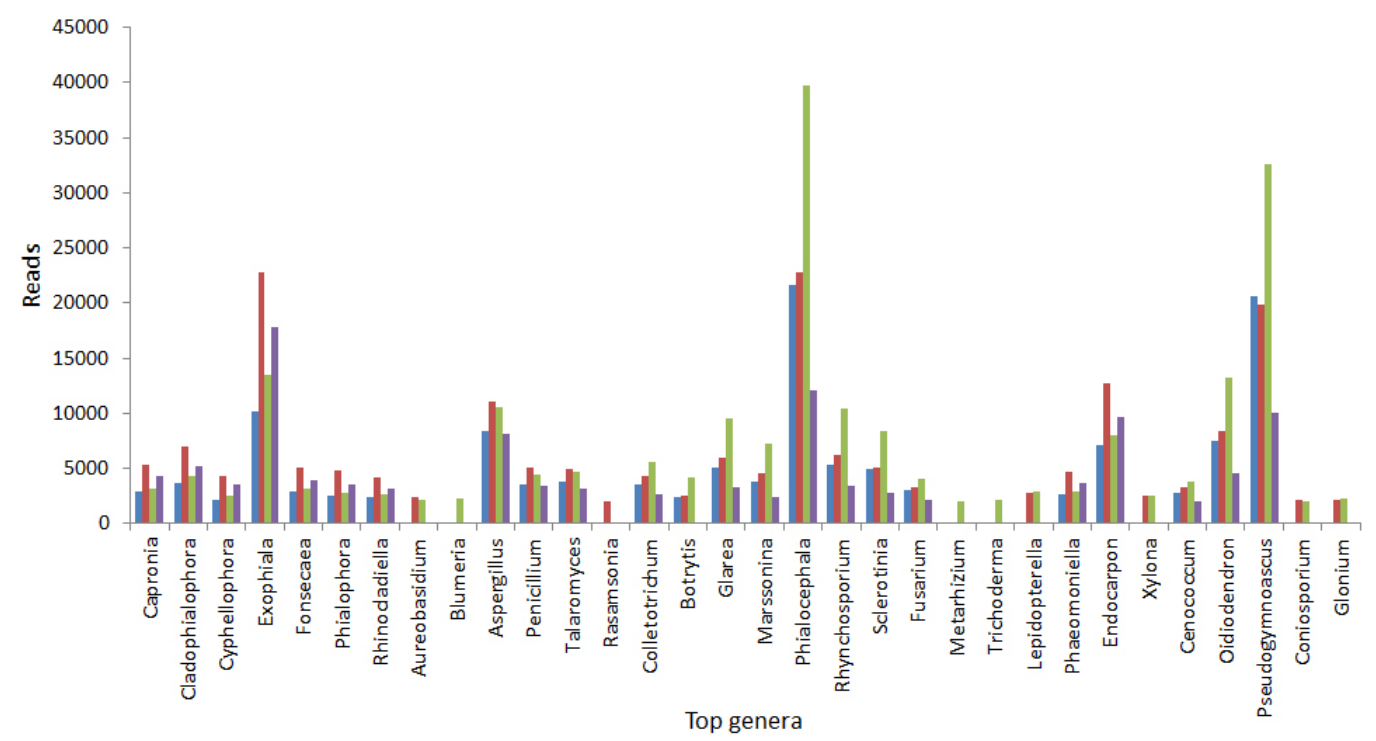

Figure 7. Top fungal genera (over 2000 reads) in upper biocrust samples. Samples taken in May are coded blue (sampling area same as sample 1) and red (sampling area same as sample 2). Samples taken in September are coded green (sampling area same as sample 1) and purple (sampling area same as sample 2).

fungi were detected in one of the samples (Figure 8). The basidiomycetes found in the lower biocrust samples were Hebeloma (within Agaricales), Rhizoctonia (within Cantharellales) and Serendipita (within Sebacinales). Mortierella (within Mortierellales) was the only zygomycete fungus. Of Ascomycota Pseudogymnoascus, Phialocephala, Aspergillus, Serendipita and Fusarium were the most abundant in both lower samples. All these genera except Serendipita were also abundant in the upper samples. The same goes for the top fungal genera in the upper samples; they were all found in the lower samples but many had less than 200 reads. Several orders of lichen forming fungi were detected, but only the genus Endocarpon (Verrucariales) registered over 200 reads.

\section{DISCUSSION}

Fungal composition in biocrust

Work on biocrust fungi has mostly dealt with the uppermost $1 \mathrm{~cm}$ or less of the soil profile. Interestingly, we found a clear difference in the fungal composition in the uppermost 5 $\mathrm{mm}$ and the next $5 \mathrm{~mm}$, which underlies the biocrust. Ascomycota fungi were found to be very dominant (mean proportion 94\%) in upper samples, whereas Basidiomycota became more pronounced in the lower samples although Ascomycota were still dominant (Table 2). The proportion of fungal DNA in the upper samples was similar to that found in forest soils with a shotgun DNA study, but in the forest soils Basidiomycota are dominant (Fierer et al., 2012). Assuming a five-fold difference in average genome sizes, this corresponds to a bacterial-to-fungal ratio of 50:1, similar to the biomass ratios seen in biological soil crust from the Colorado Plateau (Bates \& Garcia-Pichel 2009).

The Icelandic liverwort-based biocrust is no exception in the dominance of Ascomycota fungi in biocrusts worldwide (Abed et al. 2013, Bates \& Garcia-Pichel 2009, Bates, Garcia-Pichel \& Nash 2010, Bates et al. 2012, Bates, Nash et al. 2010, Zhang et al. 2018). Pleosporales and Hypocreales within Ascomycota and 


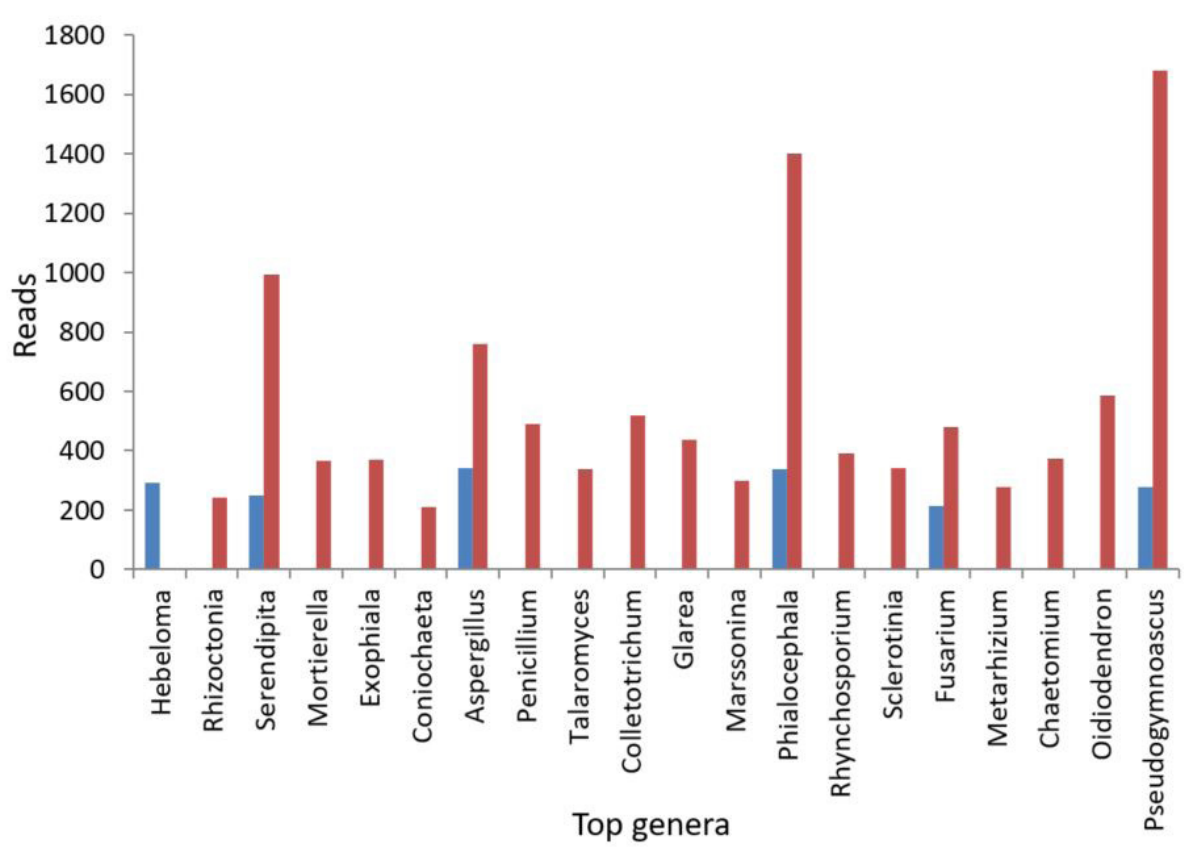

Figure 8. Top 20 fungal genera (over 200 reads) in lower biocrust samples taken in September. The sample coded blue was taken from the same sampling area as sample 1. The sample coded red was taken from the same sampling area as sample 2. Hebeloma, Rhizoctonia and Serendipita are within Basidiomycota. Mortierella is within Mucoromycota (zygomycete fungi). Other genera are all within Ascomycota.

Mortierellales within the Zygomycota have been found to be widely distributed and often abundant within biocrusts (Abed et al. 2013, Bates \& Garcia-Pichel 2009, Bates, GarciaPichel \& Nash 2010, Bates, Nash et al. 2010, Maier et al. 2016). These orders were found in all the samples, although the ascomycete orders Helotiales and Chaetothyriales were more abundant than other orders.

The most common genera found so far in biocrust studies, Alternaria and Acremonium (Abed et al. 2013, Bates \& Garcia-Pichel 2009, Bates, Garcia-Pichel \& Nash 2010, Bates, Nash et al. 2010, Maier et al. 2016, Grishkan \& Kidron 2013) were found in all samples but were not abundant. Penicillum was among the top genera found in the upper biocrust and this fungus was also found dominant in Norwegian biocrust (Borchhardt et al. 2019). Among genera found to be abundant in other biocrust studies, Fusarium and Endocarpon were the only ones among the top genera found in below ground samples.

\section{Differences in fungal composition between depths}

A difference in fungal biomass between depths in biocrust was found. Sporangia were abundant at the surface (Figure 3 ) compared to below ground ( $5 \mathrm{~mm}$ and $20 \mathrm{~mm}$ ) and the sporangial volume was higher at the surface (Table 1). This may be due to fungal gravitropism or phototropism, common among fungi (Häder 2018) and greater availability of nutrients near the surface. Large hyphae were also more common at the surface (Table 1) than below ground (5 $\mathrm{mm}$ and $20 \mathrm{~mm}$ ). This might be partially due to large hyphae forming asexual spores that break off hyphae, or arthrospores, and such propagules are more abundant at the surface as are sporangia.

Although small hyphae and hyphae outside plants were more common at the surface than 
below ground the difference between depths was not significant. Hyphae within plant tissues were also more common at the surface than below ground (Table 1). Only singular differences in hyphal or sporangial volumes were noticed. Differences in sampling times may have contributed to this variation, but only minor differences were seen in the phylogenetic composition of samples from a single site in May vs. September (Figure 7). Nevertheless, temporal differences can be expected and can be monitored by extended sampling and analysis.

The volume of hyphae within plant tissues correlated with vegetation type and depth (Figure 6), reflecting a greater frequency of subsurface plant material such as roots. Fungal material was observed within plant tissues (Figure 2d), suggestive of arbuscular mycorrhiza, but DNA sequences from the Glomerales were found at a very low level. Basal lineages of liverworts associate with arbuscular mychorrhiza, but not the Jungermanniopsida, which are known to associate with ascomycytes as well as basidiomycetes, including the Sebacinales (Pressel et al. 2010). Some of the ascomycete genera frequently observed in this study, e.g. the dark-septate Phialophora and Phialocephala, are thought to form mycorrhizal associations with plants (Jumpponen et al. 1998, Newsham et al. 2009).

\section{Conclusion}

This study describes the structure and composition of well-developed fungal communities characteristic of liverwort biocrusts in Iceland. No comparisons with biocrust fungi in Iceland could be made since this is the first study on biocrust fungi in Iceland. Although this fungal community shows many similarities to those characterized in other types of biocrusts, it also shows distinctive differences, e.g. in taxonomic composition. As in other biocrusts, the fungi influence physical composition and presumably nutrient cycling (Oddsdottir 2010), including connections to pioneering bryophytes and vascular plants invading the biocrust (Collins et al. 2008, Green et al. 2008). It is probable that such nutrient translocation is mediated by mycorrhizal associations of several fungal genera identified in this study. These issues are worthy of further studies, especially in biocrusts transitioning to other plant communities.

\section{ACKNOWLEDGMENTS}

We thank Rúna Björk Smáradóttir for access to the metagenome analysis data for the estimation of fungal composition as well as for general assistance. We also thank Alejandro Salazar Villegas and Denis Warshan for technical help.

\section{REFERENCES}

\section{Abed RMM, Al-Sadi AM, Al-Shehi M, Al-Hinai}

S \& Robinson MD 2013. Diversity of free-living and lichenized fungal communities in biological soil crusts of the Sultanate of Oman and their role in improving soil properties. Soil Biology \& Biochemistry 57, 695-705.

https://doi.org/10.1016/j.soilbio.2012.07.023

Bates ST \& Garcia-Pichel F 2009. A cultureindependent study of free-living fungi in biological soil crusts of the Colorado Plateau: Their diversity and relative contribution to microbial biomass. Environmental Microbiology 11, 56-67. https://doi.org/10.1111/j.1462-2920.2008.01738.x

Bates ST, Garcia-Pichel F \& Nash TH 2010. Fungal components of biological soil crusts: insights from culture dependent and culture independent studies. Bibliotheca Lichenologica 105, 197-210.

Bates ST, Nash TH \& Garcia-Pichel F 2012. Patterns of diversity for fungal assemblages of biological soil crusts from the southwestern United States. Mycologia 104, 353-361.

https://doi.org/10.3852/11-232

Bates ST, Nash TH, Sweat KG \& Garcia-Pichel F 2010. Fungal communities of lichen-dominated biological soil crusts: Diversity, relative microbial biomass, and their relationship to disturbance and crust cover. Journal of Arid Environments 74, 1192-1199.

https://doi.org/10.1016/j.jaridenv.2010.05.033

Bates ST, Reddy GS \& Garcia-Pichel F 2006. Exophiala crusticola anam. nov. (affinity Herpotrichiellaceae), a novel black yeast from biological soil crusts in the Western United States. International Journal of Systematic and 
Evolutionary Microbiology 56, 2697-2702.

https://doi.org/10.1099/ijs.0.64332-0

Belnap J 2001. Comparative structure of physical and biological soil crusts. In: Belnap J \& Lange OL (eds) Biological Soil Crusts: Structure, Function, and Management. Ecological Studies 150. Springer, Berlin, Heidelberg, pp. 177-191.

https://doi.org/10.1007/978-3-642-56475-8

Belnap J, Kaltenecker JH, Rosentreter R, Williams J, Leonard S \& Eldridge D 2001. Biological Soil Crusts: Ecology and Management. US Department of Interior, Denver, Colorado, 110 p. Accessed 24.8.2019 at https://archive.org/ details/biologicalsoilcr00beln

Belnap J, Weber B \& Büdel B 2016. Biological soil crusts as an organizing principle in drylands. In: Weber B, Büdel B \& Belnap J (Eds). Biological Soil Crusts: An Organizing Principle in Drylands, Ecological studies 226. Springer, Cham, Switzerland. pp. 3-14. https://doi.org/10.1007/978-3-319-30214-0_1

Borchhardt N, Baum C, Mikhailyuk T \& Karsten U 2017. Biological soil crusts of Arctic Svalbard Water availability as potential controlling factor for microalgal biodiversity. Frontiers in Microbiology 8,1485 .

https://doi.org/10.3389/fmicb.2017.01485

Borchhardt N, Baum C, Thiem D, Köpche T, Karsten U, Leinweber P \& Hrynkiewicz K 2019. Soil microbial phosphorus turnover and identity of algae and fungi in biological soil crusts along a transect in a glacier foreland. European Journal of Soil Biology 91, 9-17.

https://doi.org/10.1016/j.ejsobi.2018.12.006

Bowker MA, Belnap J, Büdel B, Sannier C, Pietrasiak N, Eldridge DJ \& Rivera-Aguilar V 2016. Controls on distribution patterns of biological soil crusts at micro- to global scales. In: Weber B, Büdel B \& Belnap J (Eds). Biological Soil Crusts: An Organizing Principle in Drylands, Ecological Studies 226. Springer, Cham, Switzerland. pp. 173198.

https://doi.org/10.1007/978-3-319-30214-0 10

Broady PA \& Weinstein RN 1998. Algae, lichens and fungi in La Gorce Mountains, Antarctica. Antarctic Science. 10, 376-385.

https://doi.org/10.1017/S0954102098000467
Collins SL, Sinsabaugh RL, Crenshaw C, Green L, Porras-Alfaro A, Stursova M \& Zeglin LH 2008. Pulse dynamics and microbial processes in arid land ecosystems. Journal of Ecology 96, 413420. https://doi.org/10.1111/j.1365-2745.2008.01362.x

EImarsdottir A, Aradottir AL \& Trlica MJ 2003. Microsite availability and establishment of native species on degraded and reclaimed sites. Journal of Applied Ecology 40, 815-823.

Fierer N, Leff JW, Adams BJ, Nielsen UN, Bates ST, Lauber CL, Owens S, Gilbert JA, Wall DH \& Caporaso JG 2012. Cross-biome metagenomic analyses of soil microbial communities and their functional attributes. Proceedings of the National Academy of Sciences of the United States of America. 109, 21390-5.

https://doi.org/10.1073/pnas.1215210110.

Green LE, Porras-Alfaro A \& Sinsabaugh RL 2008. Translocation of nitrogen and carbon integrates biotic crust and grass production in desert grassland. Journal of Ecology 96, 10761085.

https://doi.org/10.1111/j.1365-2745.2008.01388.x

Grishkan I \& Kidron GJ 2013. Biocrust-inhabiting cultured microfungi along a dune catena in the western Negev Desert, Israel. European Journal of Soil Biology 56, 107-114.

https://doi.org/10.1016/j.ejsobi.2013.03.005

Gudmundsdottir P 2018. Fungal Structure and Composition in Liverwort-based Biocrust (Master's thesis). University of Iceland, Reykjavík. 95 p. Accessed 24.8 .2019 at https://skemman.is/ handle/1946/30521

Hallgrimsson H 2015. Mosaskorpa [Liverwort biocrust]. Náttúrufrceðingurinn 85, 157-160. [In Icelandic].

Hallgrimsson H 2010. Sveppabókin: Íslenskir sveppir og sveppafrcedi [The book of fungi: Icelandic fungi and mycology]. Skrudda, Reykjavik, 632 p. [In Icelandic].

Hallgrimsson H \& Eyjolfsdottir GG 2004. Íslenskt sveppatal I Smásveppir [Checklist of Icelandic fungi I Microfungi]. Fjölrit náttúrufrceðistofnunar 45. 189 p. Accessed 24.8.2019 at http://utgafa.ni.is/ fjolrit/Fjolrit_45.pdf [In Icelandic]. 
Häder DP 2018. Gravitropism in Fungi, Mosses and Ferns. In: Gravitational Biology I. Springer Briefs in Space Life Sciences. Springer. Berlin, Germany, pp 67-74

https://doi.org/10.1007/978-3-319-93894-3_5

Jumpponen A, Mattson KG \& Trappe JM 1998. Mycorrhizal functioning of Phialocephala fortinii with Pinus contorta on glacier forefront soil: Interactions with soil nitrogen and organic matter. Mycorrhiza. 7, 261-265.

https://doi.org/10.1007/s005720050190.

Leck A 1999. Preparation of lactophenol cotton blue slide mounts. Community Eye Health, 12, 24.

Magnusson SH, Magnusson B, Elmarsdottir A, Metusalemson S \& Hansen HH 2016. Vistgerðir á landi [Terrestrial habitats]. In: Ottosson JG, Sveinsdottir A \& Hardardottir M (Eds.) Vistgerðir á Íslandi [Habitats in Iceland]. Fjölrit Náttúrufraeðistofnunar 54. pp. 17-169. [In Icelandic].

Magnusson SH, Magnusson B, Ólafsson E, Guðjonsson G, Guðmundsson GA, Kristinsson, H, Egilsson K, Skarphéðinsson KH, Heiðmarsson S \& Ottosson JG 2009. Vistgerðir á miðhálendi Íslands: Flokkun, lýsing og verndargildi [Habitats in the central highlands of Iceland: Classification, description and conservation value]. Natturufraedistofnun Islands. 174 p. [In Icelandic].

Maier S, Muggia L, Kuske CR \& Grube M 2016. Bacteria and non-lichenized fungi within biological soil crusts. In: Weber B, Büdel B \& Belnap J (Eds). Biological Soil Crusts: An Organizing Principle in Drylands, Ecological studies 226. Springer, Cham, Switzerland. pp. 81-100.

https://doi.org/10.1007/978-3-319-30214-0_5

Menzel P, Ng KL \& Krogh A 2016. Fast and sensitive taxonomic classification for metagenomics with Kaiju. Nature Communications 7, 11257.

https://doi.org/10.1038/ncomms11257

Natturufraedistofnun Islands 2017. Kortasja Natturufraedistofnunar Islands [Maps of the Icelandic Institute of Natural History]. Accessed 29.5.2018 at http://vistgerdakort.ni.is [In Icelandic].
Newsham KK, Upson R \& Read DJ 2009.

Mycorrhizas and dark septate root endophytes in polar regions. Fungal Ecology 2, 10-20.

https://doi.org/10.1016/j.funeco.2008.10.005

Oddsdottir E 2010. Distribution and Identification of Ectomycorrhizal and Insect Pathogenic Fungi in Icelandic Soil and Their Mediation of Rootherbivore Interactions in Afforestation (doctoral dissertation). University of Iceland, Reykjavík. 123 p. Accessed 24.8.2019 at https://skemman.is/ handle $/ 1946 / 5620$ ?locale $=$ en

Parija SC \& Prabhakar PK 1995. Evaluation of lacto-phenol cotton blue for wet mount preparation of feces. Journal of Clinical Microbiology 33, 1019-1021. Accessed 24.8.2019 at https://www. ncbi.nlm.nih.gov/pmc/articles/PMC228091/

Parija SC, Shivaprakash MR \& Jayakeerthi SR 2003. Evaluation of lacto-phenol cotton blue (LPCB) for detection of Cryptosporidium, Cyclospora and Isospora in the wet mount preparation of stool. Acta Tropica 85, 349-354. https://doi.org/10.1016/S0001-706X(02)00265-6

Perez-Moreno J \& Read DJ 2000. Mobilization and transfer of nutrients from litter to tree seedlings via the vegetative mycelium of ectomycorrhizal plants. New Phytologist 145, 301-309.

https://doi.org/10.1046/j.1469-8137.2000.00569.x

Preibisch S, Saalfeld S \& Tomancak P 2009. Globally optimal stitching of tiled 3D microscopic image acquisitions. Bioinformatics 25, 1463-1465. https://doi.org/10.1093/bioinformatics/btp184

Pressel S, Bidartondo M, Ligrone R, \& Duckett J 2010. Fungal symbioses in bryophytes: New insights in the twenty first century. Phytotaxa, 9, 238-253.

http://dx.doi.org/10.11646/phytotaxa.9.1.13

R-Core-Team 2017. R: A Language and Environment for Statistical Computing. $R$ Foundation for Statistical Computing. Accessed 9.5.2018 at https://www.R-project.org/

Rasconi S, Jobard M, Jouve L \& Sime-Ngando T 2009. Use of calcofluor white for detection, identification, and quantification of phytoplanktonic fungal parasites. Applied and Environmental Microbiology 75, 2545-2553. https://doi.org/10.1128/AEM.02211-08 
RStudio 2018. RStudio: Integrated Development Environment for $R$ (Version 1.1.423). Accessed 9.5.2018 at http://www.rstudio.org/

Rueden CT, Schindelin J, Hiner MC, DeZonia BE, Walter AE, Arena ET \& Eliceiri KW 2017. ImageJ2: ImageJ for the next generation of scientific image data. BMC Bioinformatics 18, 529. https://doi.org/10.1186/s12859-017-1934-z

Schindelin J, Arganda-Carreras I, Frise E, Kaynig V, Longair M, Pietzsch T, Preibisch S, Rueden C, Saalfeld S, Schmid B, Tinevez JY, White DJ, Hartenstein V, Eliceiri K, Tomancak P \& Cardona A 2012. Fiji: An open-source platform for biological-image analysis. Nature Methods 9, 676-682.

https://doi.org/10.1038/nmeth.2019

Spatafora JW, Chang Y, Benny GL, Lazarus K, Smith ME, Berbee ML, Bonito G, Corradi N, Grigoriev I, Gryganskyi A, James TY, O'Donnell K, Roberson RW, Taylor TN, Uehling J, Vilgalys R, White MM \& Stajich JE 2016. A phylum-level phylogenetic classification of zygomycete fungi based on genome-scale data. Mycologia 108, 10281046.

https://doi.org/10.3852/16-042

Steven B, Hesse C, Gallegos-Graves LV, Belnap J \& Kuske CR 2016. Fungal diversity in biological soil crusts of the Colorado Plateau. In: Ralston BE (eds.) Proceedings of the 12th Biennial Conference of Research on the Colorado Plateau. US Geological survey scientific investigations report 2015-5180, pp 41-47.

https://doi.org/10.3133/sir20155180

Steven B, Kuske CR, Gallegos-Graves LV, Reed SC \& Belnap J 2015. Climate change and physical disturbance manipulations result in distinct biological soil crust communities. Applied and Environmental Microbiology 81, 7448-7459.

https://doi.org/10.1128/AEM.01443-15

Zhang Y, Aradottir AL, Serpe M, \& Boeken B 2016. Interactions of biological soil crusts with vascular plants. In: Weber B, Büdel B \& Belnap J (Eds.) Biological Soil Crusts: An Organizing Principle in Drylands, Ecological studies 226. Springer, Cham, Switzerland. pp. 385-406.

https://doi.org/10.1007/978-3-319-30214-0_19
Zhang, T, Wang, NF, Liu, HY, Zhang, YQ, \& Yu, LY 2016. Soil $\mathrm{pH}$ is a key determinant of soil fungal community composition in the Ny-Ålesund Region, Svalbard (High Arctic). Frontiers in Microbiology, 7, 227.

https://doi.org/10.3389/fmicb.2016.00227

Zhang BC, Zhang YQ, Li XZ \& Zhang YM 2018. Successional changes of fungal communities along the biocrust development stages. Biology and Fertility of Soils 54, 285-294.

https://doi.org/10.1007/s00374-017-1259-0

Manuscript received 2 April 2019

Accepted 21 August 2019 